\title{
Improving the Training System for Managers of Organisations in the Context of the New Industrialisation of Russia
}

\author{
Elena Abanina ${ }^{1, *}, Y u . S$. Sergeenko ${ }^{1}$, Iuliia Litvinova ${ }^{2}, Y u . M$. Nikitenko $^{2}$, and Natalya \\ Bobrakova $^{2}$ \\ ${ }^{1}$ Saratov State Law Academy, 410056 Saratov, Russia \\ ${ }^{2}$ Pushkin Leningrad State University, 196605 Pushkin, Russia
}

\begin{abstract}
The key to success of the new industrialisation is not just economic modernisation in terms of information technology, robotics and other technical innovations. The modernisation of manufacturing plants is also about safety, both internally (in terms of worker safety) and externally (in terms of environmental safety). In this process, the head of such enterprises and organisations will play a key role. Given the new requirements and the new vector of economic development ("green economy"), the requirements for all organisations are increasing, and there is a need to improve the skills of managers of organisations, so that their training meets the new conditions of life. The paper considers and analyses the prerequisites for the formation of a unified system of training for managers of organisations in the field of occupational health and environmental safety. Legislative problems in separate directions of training for managers have been revealed. Proposals for the formation of a unified system of training for managers have been made. Key words: new industrialization, manager of organisation, environmental safety, environmental protection, labour protection.
\end{abstract}

\section{Introduction}

In the current context of Russia's new industrialisation, where economic, social and health care modernisation processes are constantly underway, there are contradictions between the economic and environmental interests of society. Despite the new economic challenges associated with the industrial revolution and the informatization of all sectors, both in Russia and in other countries, we must not forget about the achievement of the Sustainable Development Goals (hereinafter also SDGs). Given the situation in the world, the essence of the SDGs is to take measures to eliminate poverty, while at the same time increasing economic growth and addressing other issues in education, health, social protection and employment, as well as facing climate change and protecting the environment.

The Sustainable Development Goals Report 2020 provides an assessment of the world's progress towards achieving the SDGs, highlighting areas where progress has been positive

\footnotetext{
* Corresponding author: elena-abanina@yandex.ru
} 
and areas where action has been insufficient. It notes that progress has been made in areas such as increasing access to electricity and women's representation in government, but these gains are offset by environmental crises such as land degradation, endangered species and unsustainable consumption and production patterns. In addition, the effects of the COVID-19 pandemic have put all sectors of the population at serious risk, with some estimates suggesting a 60 per cent drop in income in the first month of the crisis, resulting in underemployment and unemployment [1]. Undoubtedly, these facts confirming the developing social and economic crises reduce the rate of achievement of the sustainable development goals. In this regard, the representatives of science and technology are faced with the dual challenge of ensuring that all spheres of life are stable while also achieving their neo-industrialisation goals.

Transition from one development model to a new type of economic growth is enabled by economic modernisation. There is no doubt that it is manufacturing that dominates the national economy and contributes immensely to the development and prosperity of both national and global economies, which is the driving force for neo-industrialisation [2]. At the same time, managers of such organisations play an important role in reorganising and supporting new solutions. One of the main requirements for the managers of organisations must be leadership training adequate to today's global challenges and domestic issues. In view of the above-mentioned requirements in the field of meeting new economic objectives while taking into account the preservation of life and health of employees and at the same time avoiding the degradation of the natural environment as a goal of sustainable development, the training of managers in the field of occupational safety and environmental protection [3] comes to the fore. These two areas are particularly required to fill management positions in companies that are potentially hazardous to the environment. The possibility of combining these directions into one training system for managers, in our opinion, is dictated by their common goal - preservation of human life and health.

The purpose of this article is to justify the creation of the unified health and safety training system for managers of organisations.

The purpose of the study is to examine the following issues step by step: to examine the prerequisites for the formation of a unified training system for managers of organisations in occupational health and safety; to conduct a comparative analysis of the legal framework for the formation of a unified training system for managers of organisations (environmental and labour law); to identify legislative and practical problems in certain areas of manager training; to develop proposals for the formation of a unified training system for managers.

\section{Materials and Methods}

The methodological basis of the study is a modern understanding of sustainable development as a development in which the needs of present generations are met by creating a sustainable green economy, sustainable use of natural resources, while the needs of future generations are not compromised. On this basis, we hypothesized that the unified training of managers in the field of occupational health and environmental safety will contribute to the achievement of new economic objectives of the organisation, taking into account the preservation of life and health of employees, while preventing deterioration of the quality of the natural environment.

First of all, the primary sources - legal acts regulating the issues of management training, both in labour and environmental legislation - have been analysed. Also, in order to develop a unified training system for managers of organisations in the field of occupational and environmental safety, scientific papers in this area have been studied, concerning rather narrow issues, which meanwhile have influenced some conclusions of the study, for example, the issue of the demand for business process automation programs for 
industrial and fire safety, labour and environmental protection and the involvement of organisation managers [4], the issue of adopting new modern professional standards, the development of internal regulatory documents of organisations, creation of centres for assessing the qualifications of employees [5]; about the peculiarities of the development of personnel potential of employees of a state company in the context of the new industrialisation of Russia [6].

General scientific methods have been used to develop an approach to creating a unified training system for managers of organisations in labour protection and environmental safety: structural-functional method, probabilistic method, special scientific methods: method of comparative legal analysis, method of legal modelling, method of legal forecasting.

\section{Results and Discussion}

After examining the preconditions for a unified training system for managers of organisations in labour protection and environmental safety, we have divided them into two groups.

First, political preconditions.

Both labour and environmental health and safety issues have recently become particularly important. At the 2019 National Week for Safety and Health at Work, the head of the International Labour Organisation (ILO), Guy Ryder, noted that the latest figures show that 2.7 million people worldwide die of occupational injuries and diseases each year, with $70 \%$ of all injuries due to human error [7].

The UN published an environmental assessment in 2019, warning that "unless urgent action is taken, the devastation to the planet will continue to put human health at increasing risk". At the same time it was pointed out that there is not enough support from business representatives who continue to cling to outdated models of production and development [8]. Therefore, it is the leaders of a new formation, of a new education that combines not only economic, but also legal and environmental knowledge that will be able to solve the above-mentioned problems.

Second, economic preconditions.

Issues of labour protection and environmental safety in the organisation require considerable financial expenditure. Financing of measures to improve working conditions and labour protection (with the exception of state unitary enterprises and federal institutions) is carried out in an amount not less than $0.2 \%$ of the cost of production (works, services). Non-compliance with labour protection requirements results in industrial accidents and occupational diseases, and the financial burden of damage compensation, rehabilitation and treatment is enormous and can reach 4\% of GDP annually in connection with industrial injuries alone. That is, the financial security of preventing the consequences of non-compliance with labour protection requirements is economically more advantageous than the financial security of the consequences of non-compliance with labour protection requirements.

The situation is similar in the field of environmental security. Financing of the organisation's activities in this area consists of financing environmental protection measures: current (expenditures on waste management, wastewater treatment, etc.) and capital (introduction of green business tools - costs for construction, purchase, reconstruction and modernisation of environmental protection facilities). In the case of noncompliance with environmental security requirements, and environmental protection in particular, organisations incur large financial losses, first, by paying administrative fines imposed and, second, by compensating the damage caused to nature, both in kind and in monetary form. For example, the total amount of current spending on environmental 
protection by enterprises in the Russian Federation as a whole in 2017 ("manufacturing industries" by type of economic activity) amounted to $133,963.9$ million rubles, or $41.7 \%$ of the total amount of environmental current spending in the Russian Federation. Violations of environmental requirements resulted in penalties of 7,673 thousand rubles. The damage caused to the environment amounted to $957,140.03$ thousand rubles, and this was only for 131 oil product pollution cases, i.e. approximately $1 \%$ of the total number of identified violations.

Thus, it is quite obvious that managers of organisations, in addition to special knowledge in their professional activity, must undergo training (preparation, retraining, and professional training) in the field of labour protection and environmental protection in the course of production activity. Of course, these categories of citizens, as a rule, already have a great experience of practical management work and special education, but since getting their first professional education they have acquired new working skills, faced new work peculiarities and difficulties, and connected with the necessity of providing safe working conditions, connected with the environmental factors, among others. In addition, the ways of production are actively changing regarding to the goals of sustainable development: new ways of economic growth with the least possible depletion of natural resources have emerged [9]; and with neo-industrialisation, training is additionally needed to move from traditional production with a potential environmental threat to nature to environmentally responsible production [10].

In order to identify differences in the legal framework for manager training in the areas outlined, we carried out a comparative analysis of Russian labour and environmental legislation in terms of establishing requirements for professional training, retraining and professional development of managers of organisations (Table 1).

Table 1. Training requirements for managers of organisations

\begin{tabular}{|c|c|c|}
\hline Requirement & Labour legislation & Environmental legislation \\
\hline $\begin{array}{l}\text { term for } \\
\text { retraining and } \\
\text { professional } \\
\text { training }\end{array}$ & $\begin{array}{l}\text { for managers required to } \\
\text { undergo special training in } \\
\text { labour safety, there are time } \\
\text { requirements for special } \\
\text { training, initially when they start } \\
\text { work for the first month, and } \\
\text { then as necessary, but at least } \\
\text { once every } 3 \text { years }\end{array}$ & $\begin{array}{l}\text { for managers required to undergo training in } \\
\text { environmental protection and environmental safety, } \\
\text { there is a requirement to have such training at the } \\
\text { time of entry into employment, and no time limits } \\
\text { are set for retraining and professional training; based } \\
\text { on the data from the organisations that provide such } \\
\text { training and issue professional training certificate, } \\
\text { the validity of the certificate is from } 3 \text { to } 5 \text { years }\end{array}$ \\
\hline $\begin{array}{l}\text { the category } \\
\text { of managers } \\
\text { required to } \\
\text { undergo } \\
\text { retraining and } \\
\text { professional } \\
\text { training }\end{array}$ & $\begin{array}{l}\text { all managers of organisations, } \\
\text { persons who manage and } \\
\text { represent their organisation in } \\
\text { relations with other subjects }\end{array}$ & $\begin{array}{l}\text { all managers of organisations, as they are responsible } \\
\text { for making decisions on business and other activities }\end{array}$ \\
\hline $\begin{array}{l}\text { the content of } \\
\text { educational } \\
\text { programs }\end{array}$ & $\begin{array}{c}\text { an exemplary program for safety } \\
\text { training has been developed and } \\
\text { the content of the program is } \\
\text { described in detail }\end{array}$ & $\begin{array}{l}\text { an exemplary program for professional training of } \\
\text { persons entitled to work with hazardous waste has } \\
\text { been approved and is divided into blocks, sections } \\
\text { and topics with their names and the allocation of } \\
\text { hours for each structural element of the program }\end{array}$ \\
\hline
\end{tabular}

The presented overview of the preconditions for a unified management training system in labour protection and the comparative analysis of labour and environmental legislation in this area confirms the need for a unified training program and the development of such a training system.

Due to the specific nature of production, it is possible to identify a separate group of organisations whose activities are more dangerous than others and, in addition to the usual negative impact, can create an environmentally hazardous situation - potentially hazardous production. In order to train managers of such organisations, taking into account different 
specialties, it is necessary to develop separate job profile diagrams, which will differ in content, set of competences, depending on the hazard class of a hazardous production facility, it can be amended and supplemented accordingly [11].

\section{Conclusions}

The aim of the unified labour health and environmental protection training system is to train the managers of organisations to ensure that the organisations have a sufficient level of protection for their employees, both in terms of labour health and environmental protection.

Stages in the establishment of a unified training system:

1. set-up stage - taking into account the requirements of labour and environmental legislation - defining the subjects of the training, the training procedure;

2. training and methodological stage - development of a unified training program, timetable and form of end-of-training certification;

3. preparatory stage - launching a pilot project of a new training program to test the validity of the program and prepare for full-scale implementation of the developed program;

4. main stage - introduction of a training program for managers of organisation in labour health and environmental protection.

The introduction of such training for managers of organisations will ensure safe production both internally (for the workers) and externally (for the environment). It is the high qualification and professionalism of the manager in this area that will enable organisations to adapt to changing economic conditions within the framework of compliance with sustainable development goals.

\section{Acknowledgements}

The reported study was funded by RFBR according to the research project № 19-011-00416.

\section{References}

1. The-Sustainable-Development-Goals-Report-2020, https://unstats.un.org/

2. Sang Xiaoming, Business and Management Research, 153 (2020)

3. E.N. Abanina, Yu.S. Sergeenko, O.V. Devyatov, O. Yu Ganyukhina, Yu.M. Nikitenko, IOP Conf. Ser.: Mater. Sci. Eng, 582(1) (2019)

4. A.S. Fomina, E.V. Glebova, E.E. Fomina, Occupational Safety in Industry, 4 (2020)

5. M.V. Druzhinia, M.V. Zakharchenko, M.A. Ananina, E.E. Solovyova, IOP Conf. Ser.: Mater. Sci. Eng, 483 (2019)

6. O. Osipova, A. Artamonov, Advances in Social Science, Education and Humanities Research, 240 (2019)

7. B.S. Lazarenko, Occupational Safety in Industry, 1 (2020)

8. Global Environment Outlook - GEO-6: Summary for Policymakers (2019)

9. B. A. Morgunov, A. M. Bagin, M. L. Kozeltsev, A. A. Terentiev, Human Ecology, 4 (2017)

10. J. Hojnik, M. Ruzzier, T. Manolova, Foresight and STI Governance, 11 (3) (2017)

11. A.L. Panishev, L.N. Gorina, Occupational Safety in Industry, 6 (2019) 